\title{
Stakeholder Collaboration in Traffic Accident Management
}

\author{
Asri Dorisman ${ }^{1 *}(\mathrm{D})$, Adji Suradji Muhammad² ${ }^{2}$, Ramadhani Setiawan ${ }^{3}$ (D) \\ ${ }^{123}$ Department of Public Administration, Universitas Maritim Raja Ali Haji \\ *Correspondence: asri.dorisman@gmail.com
}

\section{ARTICLE INFO}

\section{Article History}

Submited; May 18, 2021

Revised; June 8, 2021

Accepted; June 28, 2021

Available online: July 08,2021

\section{Keyword}

Collaborative Governance

Stakeholders

Traffic

\begin{abstract}
This research aims to determine how the collaboration process between stakeholders in response to traffic accidents in Kota Tanjungpinang. In Kota Tanjungpinang accident numbers are still quite high from year to year. In response to traffic accidents in Kota Tanjungpinang some stakeholders such as Polres Tanjungpinang, Dinas Perhubungan Kota Tanjungpinang, PT. Jasa Raharja (Persero) Perwakilan Tanjungpinang, Dinas Pekerjaan Umum dan Penataan Ruang Kota Tanjungpinang, Dinas Perumahan Rakyat, Kawasan Permukiman, Kebersihan dan Pertamanan Kota Tanjungpinang collaborate. Data collection methods in the form of interviews that are conducted to the informant interested in the implementation of Collaborative governance process. The analysis of data obtained is carried out through data collection, data verification, data presentation, and withdrawal of conclusions. The results obtained from this research are Collaborative governance in response to this traffic accident has fulfilled several factors of 5 factors in collaboration according to the Ansell and Gash Theory (2007), a factor that is fulfilled by collaboration This is (1). Comitment to process in the collaboration of countermeasures traffic accidents see the commitment of each stakeholder and confidence in providing the best service for the countermeasures of traffic accidents. (2). The Trust building in the collaboration in response to the trust building traffic accidents between stakeholders has already run well in carrying out their roles.
\end{abstract}

\section{INTRODUCTION}

The development of science and technology in a decade grew quite rapidly, so that growth in various fields of people's lives took place very quickly as well. This growth has a good impact on the community and also the problems experienced by the community. One of the problems that need attention in Indonesia today is traffic accidents which are getting worse and worse. Traffic accidents are one of the health problems that are classified as noncommunicable diseases. The negative impact of traffic accidents such as material loss, illness, and death can affect the health status of the community. Therefore, it is necessary to make countermeasures to minimize traffic accidents as stated in the Decree of the Minister of Health No. 1116 of 2003 concerning Guidelines for the Implementation of a Health Epidemiological 
Surveillance System. According to the World Health Organization (WHO), the number of deaths from traffic accidents worldwide has reached 1.2 million people die each year on the roads, with millions more suffering serious injuries and living with long-term adverse health consequences. Globally, road-damaged traffic is the leading cause of death among young people, and the leading cause of death among those aged 15-29, ranking first. In the age group of 30-44 years, reaching 2.4 million/year, this number ranks 3rd below the mortality rate due to HIVIAIDS infection and Turboculosis (TBC). (http://m.detik.com)

The government sector includes the Tanjungpinang City Police Resort Traffic Unit, Tanjungpinang City Transportation Service, PT. Jasa Raharja (Persero) Representative of Tanjungpinang, Department of Public Housing, Residential Areas, Cleanliness and Parks of Tanjungpinang City, and Department of Public Works and Spatial Planning of Tanjungpinang City. These stakeholders have their respective roles in dealing with traffic accidents to reduce the number of traffic accidents themselves. The various problems above should be solved by a collaborative approach between stakeholders, with the availability of regulations that may involve stakeholder involvement in the Tanjungpinang City area, it is hoped that there will be significant results or changes to the handling of traffic accidents towards a better direction (zero accident).

\section{Collaborative Concepts and Definitions}

The collaboration process is used to describe the practice of two or more parties in achieving a common goal. In this case, collaboration also involves the work process of each and work together in achieving a common goal. The collaboration carried out by the organization is expected to get innovative, breakthrough, or joint achievements that are satisfying for those who collaborate. Collaboration can also lead to development within the organization and realize a shared vision in a complex environment. There are many definitions of collaboration put forward by various experts with various perspectives. The various understandings are based on the same principles, namely about togetherness, cooperation, sharing of tasks, equality, responsibility, and accountability. However, a complete and comprehensive definition for collaboration is not easy. In general, collaboration is a relationship between organizations that participate and mutually agree to jointly achieve goals, share information, share resources, share benefits, and are responsible for joint decision making to solve various problems.

Tadjudin (Raharja, 2010) Collaboration is the action of the parties to produce mutual satisfaction on a "win-to-win" basis. In the perspective of cooperation between stakeholders, collaboration is a concept of relations between organizations, relations between governments, strategic alliances, and multi-organizational networks. Tadjudin concluded that collaboration discusses the cooperation of two or more stakeholders to manage the same resources, which is difficult to achieve when done individually. Collaboration is not limited by a certain time or period, as long as there are matters that have an allegation or intersection with other parties, collaboration is still needed. Collaborating requires joint planning so that the responsibility for its implementation becomes a shared responsibility. This is as stated by (Lindeke \& Sieckert, 2005), which says collaboration is a complex process that requires knowledge sharing that is planned, deliberate, and becomes a shared responsibility.

In essence, the purpose of collaboration is to achieve a common goal by helping each other. This is as stated by (Syani, 1994), collaboration is a form of social process, in which there are certain activities aimed at achieving common goals by helping each other and understanding each other's activities. Furthermore (Nawawi, 1984) explains that the notion of collaboration is an effort to achieve shared goals that have been set through the division of tasks/work, not as a work box but as a work unit, all of which are directed at achieving goals. Collaboration knows no form and place. Collaboration is an exchange of views or ideas that provide perspectives to all collaborators or parties involved. Effective relationships between professional collaborators require mutual respect, either agree or disagree that is achieved in the interaction. Collaborative partnerships are a good business because they produce expected outcomes that are better for investors or consumers in an effort to invest that have 
an impact on increasing economic growth and increasing welfare for both the country and the community. In the public sector, for example, collaboration can be understood as a process of togetherness, cooperation, sharing of tasks, equality, and responsibilities between several entities whose activities are interconnected. Collaboration in the public sector can be done with efforts to produce public goods and services in order to meet the needs and rights of the public where the collaborating parties have the same goal. Therefore, there is a common perception, willingness to proceed, provide mutual benefits, honesty, and prioritizing interests based on the community or consumers. The collaborating entities can be from the government, civil society, and the private sector. The main objective of public sector collaboration is to improve services to the community.

Furthermore (Marshall, 1995) says that collaboration is a fundamental process of a form of cooperation that breeds trust, integrity and breakthrough through the achievement of consensus, ownership and integration in all aspects of the organization, "It is a principle based process of working together, wich produces integrity and breakthought result by building true concensus, ownership, and aligment in all aspects of the organization." In the 21st (twentyfirst) century, collaboration is the main approach that can replace the hierarchical approach. The hierarchical approach is considered an obsolete approach given that such an approach (hierarchy) requires a long and multilevel process. This is as stated by Edward, "Collaboration is the premier candidate to replace hierarchy as the organizing principle for leading and managing the 21st century workplace". According to Graddy, there are several variables that play an important role in the success of inter-organizational cooperation. Some of these important variables include; division of labor between institutions, institutional structure, coordination (operational interaction). Meanwhile, the factors that determine the success of cooperation include; faktor lead agency, faktor service delivery, and faktor infrastruktur. Characteristics and Principles in Collaborative, according to (Lestari \& Maliki, 2001) that there are five (5) main components in collaboration:

1. Collaborative Culture. A set of basic values that shape business behavior and attitudes. What is meant here is the culture of the people who will collaborate.

2. Collaborative Leadership. Togetherness that is a situational function and not just a hierarchy of positions involving everyone in the organization.

3. Strategic Vision. The guiding principles and overall goals of the organization are based on lessons based on internal cooperation and strategically focused on the uniqueness and role of value added in the marketplace.

4. Collaborative Team Process. A collection of non-bureaucratic work processes managed by collaborative teams of professional collaboration who are fully responsible for its success and learn the skills that enable them to become independent.

5. Collaborative Structure. Self-improvement of business support systems (especially information systems and human resources) to ensure the success of a collaborative workplace. Its members are an internal group that sees the organization as a customer and focuses on quality in all aspects of its work.

Referring to the opinion (Lestari \& Maliki, 2001), it can be seen that collaboration is one of the characteristics in the main negotiation strategy to reach mutual agreement from the different interests of the parties who actually have the same interest in a goal. In other words, the key to successful collaboration is the question "which is the best way we will take to achieve a common goal". In the organizational context, each party involved in the collaboration must complement each other's work culture framework, so that it is strong enough to replace the hierarchy. The framework does not have to be a program or technique or a sophisticated way to manipulate the future, but must be based on basic principles, promote stable working relationships, encourage the setting of new provisions, and enable leaders to use values togetherness in decision making.

Thus, it can be formulated that collaboration has the following characteristics; the existence of a work culture that is independent of the hierarchy so as to encourage the determination of the making of new provisions in order to empower each party or actor to achieve common goals. Collaborative basic values, there are a number of values in 
collaboration. These values must be a guide for collaborators so that what is a common goal can be achieved. According to (Djumara, 2008) there are seven basic values (The seven core values) that are used to develop working relationships with the concept of collaboration, namely:

1. Respect for others (Respect for people). The main foundation of any organization is the satisfaction of each individual. Everyone who will collaborate wants a strong position and a common ground. They want high personal satisfaction and or a work environment that supports and encourages satisfaction with themselves.

2. Respect and integrity provide recognition, work ethic (honor and integrity). In many cultures, honor and integrity shape individual behavior.

3. Sense of belonging and alliance (Ownership and alignment). When all employees feel they have their place of work, work and company, they will take good care of it.

4. Consensus (Consensus). It is a general agreement that the greatest utility is a working relationship based on win-win amounts to. In a collaborative workplace $100 \%$ decisions must be fully agreed to achieve a win-win. This means that they must overcome their disagreements as a strong effort to achieve their goals.

5. Full of responsibility and accountability (Full responsibility and Accountability). In the hierarchical paradigm, people usually become closed to one another, because of their job descriptions, because of their duties and because of their organizational units. The fact is that each person will only be responsible for the to-do list.

6. Trust-based Relationship. Everyone wants trust and openness at work. In principle they also want to be trusted. However, trust does not come easily. In fact, many of them do not trust each other. This is what makes it difficult in an organization.

7. Recognition and growth. Equally important in a collaborative workplace is an effort to encourage people to want to work, and to immediately give recognition to one's work for all team or group members.

Collaborative forms, based on some references, there are three types of collaboration based on differences between group organizations or within group attitudes, namely:

a. Primary Collaboration; The main feature of primary collaboration is that the group and the individual are truly merged into one. According to (Ahmadi, 2004) the group contains the whole life rather than the individual, and each pursues each other for their respective jobs, for the benefit of all members in the group. Examples are daily routine life in speech, family life in primitive societies and others. According to (Narwoko, 2004) the main characteristic of this type of collaboration is that these small, face-to-face primary groups, individuals tend to prefer working in teams as team members rather than working as individuals.

b. Secondary collaboration; If primary collaboration is characteristic of primitive society, then secondary collaboration is characterized by the opposite. Secondary collaboration is typical of modern society. According to (Ahmadi, 2004), this secondary collaboration is highly formalized and specialized, and each individual only evokes a part of his life to the group that is united with it. The attitude of the people here is more individualistic and calculating.

c. Tertiary Collaboration; Unlike the case with Primary and Secondary collaboration types, Tertiary Collaboration is based on a latent conflict. According to (Ahmadi, 2004) Tertiary Collaboration is based on the attitudes of the parties who collaborate are purely opportunistic. Their organization is very loose and breaks easily. If the shared tools no longer help each party in achieving its goals. For example, the relationship between workers and company leaders, the relationship between two parties in an effort to fight a third party.

\section{Governance}

The term governance was originally used as a measure by the World Bank in reports on government development performance in South African countries, then expanded rapidly after being used by various other international aid agencies such as the IMF, UNDP, ORCD, etc. because it was used as a policy basis in determining aid politics. and loans to third world 
countries. The use of the term governance as a different concept from government, has been effectively popularized by the World Bank since 1989. In a report entitled "Sub-Saharan Africa: From Crisis to Sustainable Growth", the World Bank (1989) defines governance as "exercise of political power to manage the nation".

In this report, the World Bank emphasizes that political legitimacy and consensus are prerequisites for sustainable development. Actors in a country, namely government, business and civil society, must work together to build a consensus. Thus, the role of the state is no longer regulatory, but only facilitative. Meanwhile, The Commission on Global Governance defines governance as "the sum of the many ways individuals and institutions, public and private, manage their common affairs". In another language Weiss (Pratikno, 2007) says that governance is a continuous process through which different interests are accommodated and realized in practice.

In general, the government is an institution or organization that has the power to make and implement laws and regulations in certain areas. There are several main tasks attached to the government as stated by (Rasyid, 2000). Rashid said that in general the main tasks of government include: "First, to ensure the security of the country from all possible attacks from outside, and to prevent internal rebellions that could overthrow the legitimate government through violent means. Second, maintaining order by preventing clashes among the community members, ensuring that any changes that occur in society can take place peacefully. Third, guarantee the implementation of fair treatment to every citizen without distinguishing any status behind their existence. Fourth, doing public works and providing services in areas that are impossible for non-governmental institutions to do, or which would be better if done by the government. Fifth, making efforts to improve social welfare: helping the poor and caring for the disabled, and neglected children: accommodating and channeling the homeless to productive activity sectors, and the like. Sixth, implementing economic policies that benefit the wider community, such as controlling the inflation rate, encouraging the creation of new jobs, promoting domestic and international trade, as well as other policies that directly guarantee the improvement of the economic resilience of the state and society. Seventh, implementing policies to maintain natural resources and the living environment, such as water, land and forests".

Furthermore, in another section (Rasyid, 2000), states that the main tasks can be summarized into 3 (three) essential functions, namely: service, empowerment, and development. Service will produce justice in society, empowerment will encourage community independence, and development will create prosperity in society. By (Ndraha, 2001), then the functions of government are then summarized into 2 (two) main functions, namely: "First, the government has a primary function or service function, as a provider of public services that are both privatized and civil services, including bureaucratic services. Second, the government has a secondary function or empowerment function, as the organizer of development and conducting empowerment programs. Observing the authority possessed by the government and the main tasks carried out, the government or government has an important meaning. According to Finer (Pamudji, 1993) government or government has at least 4 (four) important meanings, namely:

1. Indicates government activities or processes, namely exercising control over other parties (the activity or the process of governing).

2. Indicate the problems (matters) of the country in which the above activities or processes are encountered (states of affairs).

3. Designate people (officials) who are burdened with the tasks of governing (people chargewidth the duty of governing).

4. Indicates the manner, method or system by which a particular society is governed (the manner, method or system by which a particular society is governed).

\section{Collaborative Governance}

The term collaborative governance is a way of managing government that directly involves stakeholders outside the country, oriented to consensus and deliberation in the collective 
decision-making process, which aims to make or implement public policies and public programs (Ansell \& Gash, 2007) Focus on collaborative governance is in public policy and issues. Public institutions do have a great orientation in policy making, the goal and process of collaboration is to achieve a degree of consensus among stakeholders. In recent decades, new forms of government have emerged to replace managerial models in policy making and implementation. Collaborative governance, has come to bring together public and private stakeholders in a collective forum with public institutions to engage in consensus-oriented decision-making. (Ansell \& Gash, 2007) trying to define Collaborative Governance as follows: "A governing arrangement where one or more public agencies directly engage non-state stakeholders in a collective decision-making process that is formal, consensus-oriented, and deliberative and that aims to make or implement public policy or manage public programs or assets". In other words, Collaborative Governance is "a governing arrangement in which one or more public institutions directly involve non-state stakeholders in a formal, consensusoriented, deliberative collective decision-making process aimed at making or implementing public policies. , manage public programs or assets".

In principle, collaboration is the involvement of non-state actors. The definition presented by (Ansell \& Gash, 2007) provides an overview of the existence of certain roles between institutions/actors. Ansell and Gash are more interested in using the term public agency, with the intention to include public institutions such as the bureaucracy, courts, legislatures, and other government agencies at the local, state and federal levels. Some other experts describe Collaborative Governance as interagency coordination as collaborative governance. From several definitions that have been put forward by the experts mentioned above, the researchers formulate that Collaborative Governance is a way of managing multi-partner government that involves various stakeholders both directly and indirectly, is consensus oriented, and takes place in the collective decision-making process. However, Collaborative Governance is not only a formal institution but can also be a way of behaving. In this case the author is more interested in analyzing or researching collaboration between stakeholders, the nature of this collaboration emphasizes more on the process, the author places more emphasis on the extent to which collaboration is carried out by stakeholders to solve problems in traffic accident prevention efforts. (Ansell \& Gash, 2007) where the collaboration process in this case can be seen from the following chart.

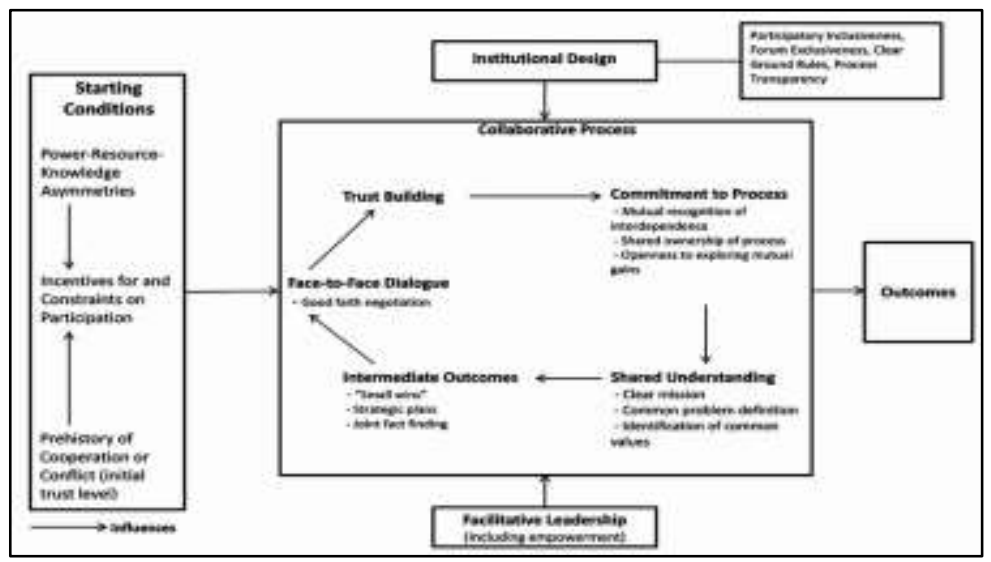

Chart 1. Ansell dan Gash Collaborative Governance Model

Initial conditions. Knowledge of the initial conditions is useful for knowing things that make it difficult for collaboration between stakeholders involved in handling traffic accidents to occur. In the initial study found the fact that there is still a sectoral ego between stakeholders in handling traffic accidents in Tanjungpinang City. This is due to the lack of mutual trust between stakeholders. Collaborative Process. In the collaboration process there are five (5) main stages, namely; 
- Phase I, face-to-face dialogue. Face-to-face dialogue is a necessary but not sufficient condition for collaboration. In interface dialogues, there are often differences in views among stakeholders, each of which wants to strengthen stereotypes and increase their antagonisms, but this dialogue is indeed necessary to build effective collaboration to reach mutual consensus. As explained earlier, the face-to-face dialogue that took place in this case brought together several stakeholders who were members of the forum. Meetings held in this forum are conducted routinely and incidentally in accordance with their respective policies. In this case, the proposal for a meeting can be submitted by one or more stakeholders who are in traffic accident management. In this first stage, each forum member participates to produce decisions and further actions in collaboration.

- Phase II, Build trust. Building trust is a time consuming process and requires a long term commitment to achieve collaborative. Therefore, if history shows antagonism between stakeholders, then policy makers or stakeholders must find time to rebuild trust. If the stakeholders are not able to build trust then a collaborative process is impossible.

- Phase III, Commitment to the process. The commitment of the stakeholders in collaborating is one of the important factors for the success of the collaboration process. However, carrying out this commitment is sometimes full of dilemmas. For example, stakeholders must comply with the results of the deliberation as a form of commitment even though the decision requires joining stakeholders with different views. Therefore, commitment requires trust so that the responsibilities of each stakeholder can be carried out properly. In this context, commitment to the process is a consequence of the involvement of each member in the forum. Handling traffic accidents requires and creates an attachment that requires parties who are committed to following a collaborative process in accordance with what has been determined.

Stage IV, Mutual understanding. At some point in the collaborative process, stakeholders must develop a common understanding. Shared understanding involves a common vision, common mission, common goals, shared ideology, clear goals, clear and strategic directions, alignment of core values, and alignment of problem definitions. In the implementation of traffic accident prevention, the "orchestra" principle is used as a pattern of coordination where there is a party who is the conductor in charge of creating harmonization to ensure a common direction in traffic accident prevention. With this principle, it will lead to active participation from each stakeholder with aligned directions and goals. Stage V, Results (outcomes). The literature shows that collaboration will occur when the goals and benefits of collaboration are concrete. The advantage of collaboration between stakeholders in handling traffic accidents in Tanjungpinang City is that collaboration will bring synergy between stakeholders. Outcomes or benefits are the benefits obtained from collaboration between stakeholders in handling traffic accidents in Tanjungpinang City.

\section{RESEARCH METHOD}

Qualitative descriptive research is used to compile a description of the object under study, the researcher first collects data at the research location, then the data is processed and interpreted and then analyzed. This study places more emphasis on Collaboration between Stakeholders in Traffic Accident Management. According to (Sugiyono, 2018) that descriptive qualitative research is a research method based on the philosophy of postpositivism which is usually used to examine natural objective conditions where the researcher acts as a key instrument. This research is related to the object to be studied, namely Collaboration between Stakeholders in Handling Traffic Accidents. In this study the researchers collected data using the following techniques and data collection; 1 . Observation is a method of collecting data by observing and recording the symptoms of the object under study. This study uses a non-participant observation technique in which the researcher is not directly involved in the process of handling traffic accidents or other activities. However, the data to be obtained from direct observation, namely data about the collaborative process carried out by the Tanjungpinang City Resort Police Traffic Unit, Tanjungpiang City Transportation Service, PT. Jasa Raharja (Persero) Tanjungpinang City, Public Housing 
Service, Settlement Areas, Cleanliness and Landscaping of Tanjungpinang City, and the Department of Public Works and Spatial Planning of Tanjungpinang City in the collaborative process in overcoming traffic accidents; 2. Interview is according to (Moleong, 2014), a conversation with a specific purpose carried out by two parties, namely the interviewer and the interviewee. In this study, researchers conducted interviews with predetermined informants. The instrument used by the researcher in the interview was an interview guide by conducting in-depth and continuous interviews in order to obtain the information they wanted to obtain.

Question items that will be asked to informants are about the collaborative process between stakeholders in handling traffic accidents in Tanjungpinang City; 3 . Documentation is done to complete the data that was not obtained from the interview process. The data in qualitative research are mostly obtained from human resources, through observation and interviews. However, there are also non-human sources, non-human resources, including documents in the form of legislation, diaries, activity reports, activity implementation guides, archives, photographs, other documents related to research. Data collected from documentation is data that supports secondary data by collecting data sourced from written data, archives and images related to the collaboration process between stakeholders in handling traffic accidents in Tanjungpinang City.

\section{RESULTS AND DISCUSSION}

In the Government's effort to implement the work program effectively, the government makes new breakthroughs by involving stakeholders outside the Government, namely the public and the private sector. The term collaborative governance is a way of managing government that directly involves stakeholders outside the country, oriented to consensus and deliberation in the collective decision-making process, which aims to make or implement public policies and public programs (Ansell \& Gash, 2007). Collaboration is carried out to achieve common goals and involving stakeholders outside the government is one way to achieve common goals (Zeho et al., 2020). Some of the stakeholders involved in collaborative governance are as follows:

1. The Tanjungpinang Police Traffic Unit which is located at Jalan Ahmad Yani Number 1 Tanjungpinang has the task of regulating, guarding, supervising, patrolling, violating, SSB, Traffic Dikmas, as well as law enforcement of ticketing and accidents

2. The transportation service has the main task of assisting the mayor in carrying out government affairs that are under the authority of the region and the co-administration tasks given to the city in the fields of road traffic, road transportation, shipping and air. In carrying out its main tasks, the Department of Transportation carries out the following functions:

a. Formulation of policies for administering government affairs which are under the authority of the Regions in the fields of Road Traffic, Road Transportation, Shipping and Air,

b. Implementation of policies on the implementation of government affairs which are under the authority of the Regions in the fields of Road Traffic, Road Transportation, Shipping and Air,

c. Implementation of evaluation and reporting on the implementation of government affairs that are under the authority of the Region in the fields of Road Traffic, Road Transportation, Shipping and Air,

d. Implementation of service administration in the context of administering government affairs that are under the authority of the Regions in the fields of Road Traffic, Road Transportation, Shipping and Air, and

e. Implementation of other functions given by the Mayor related to its duties and functions.

3. The 1945 Constitution Article 34 paragraph (2) The State shall develop a social security system for all people and empower the weak and incapable in accordance with human dignity. In fact, the spirit contained in the article is to instruct state administrators to always 
provide protection and social security and empower the community to achieve a decent life in accordance with human dignity. Due to an urgent need in the interest of protecting the public at large, the Government through its policies establishes business entities and the laws that regulate them. Law No. 33 of 1964 and Law no. 34 of 1964 and Government Regulation no. 8 of 1965, the Government Regulation was enacted on March 30, 1965, however, it came into force with retroactive effect on January 1, 1965 to form the State Insurance Company for Loss of Jasa Raharja. Thus PT Asuransi Jasa Raharja becomes a leading company in the field of compulsory insurance in line with the needs of the community. PT Jasa Raharja (Persero) in carrying out its duties and responsibilities to operate it nationally. Jasa Raharja always tries to get closer to the community by increasing the number of service offices. Currently Jasa Raharja has so many service offices spread throughout Indonesia. This effort is made to speed up the service process to the entire community. Therefore, Jasa Raharja is trying to increase the number of service offices. The Jasa Raharja office is positioned as a service unit to the community. Jasa Raharja places employees in all SAMSATs throughout Indonesia. This has resulted in an increase in the completion time of the compensation process.

4. At first the Parks Cleaning Service was established in 2005 which is located in the market, then around 2006-2007 the cleaning sector broke up and became a field in the kimpraswil, and in 2008-2012 it became the Parks and Cemetery Cleaning Office. The Tanjungpinang City Parks and Cemetery Cleanliness Office was formed based on the Mayor's Decree number: 22 of 2009 concerning the Description of Main Duties and Organizational Functions and Work Procedures of the Tanjungpinang City Parks and Cemetery Cleanliness Office has the main task in terms of providing services to the community in the field of cleanliness of the beauty of the city, and then in 2013 the City Planning Service for Gardening and Cemetery was formed. With the regulation of the Mayor of Tanjungpinang Number 58 of 2012 concerning the Description of the Main Duties and Functions of the Organization and Work Procedure of the City Planning Service, the Sanitation of the Parks and Cemeteries of the City of Tanjungpinang, then in 2015 based on the Regulation of the Mayor of Tanjungpinang Number 12 of 2015 concerning the Description of the Main Duties and Functions of the Organization and Administration. With the work of the Tanjungpinang City Cleanliness, Parks and Cemetery Service, the Sanitation, Parks and Cemetery Service was formed and in the end the Parks and Cemetery Cleaning Service added the name of the service where the name was the Public Housing, Settlement, Clean and Parks Office of Tanjungpinang City in 2016. The Department of Public Housing, Residential Areas, Cleanliness and Parks was formed based on the Tanjungpinang Mayor Regulation Number 45 of 2016 concerning the Description of Main Duties, Organizational Functions and Work Procedures of the Department of Public Housing, Settlement Areas, Cleanliness and Parks of Tanjungpinang City.

5. The City of Tanjungpinang was established through Law Number 5 of 2001 which was signed by the President of the Republic of Indonesia Abdurrahman Wahid on June 21, 2001, and recorded in the State Gazette of the Republic of Indonesia of 2001 Number 85. Inauguration of the City of Tanjungpinang by the Minister of Home Affairs and Regional Autonomy Hari Sabarno, held simultaneously with 11 other cities on October 17, 2001 in Jakarta. The inauguration date of Tanjungpinang City is used as a moment to commemorate the anniversary of Tanjungpinang City as an autonomous city. On that basis, the Tanjungpinang city government formed several SKPD, one of which was the Tanjungpinang City Public Works Department.

As an elaboration of the vision of the Tanjungpinang City Public Works and Spatial Planning Office above, the mission of the Public Works and Spatial Planning Office was formulated in order to realize the vision of "Availability of quality and environmentally friendly Urban Infrastructure in a sustainable manner to support the improvement of government services and the smooth rotation of the community's economy towards Tanjungpinang. 
Prosperous". The Department of Public Works and Spatial Planning has the following missions:

a. Carry out the arrangement and maintenance of river channels, coastal channels and urban drainage in order to realize a flood-free Tanjungpinang.

b. Organizing the development of infrastructure for the management and provision of raw water to meet the drinking water needs of the community.

c. Develop an urban road network system through the construction of new road sections to facilitate access to new tourism, industrial, trade and residential development areas.

d. Improving the function of road services by increasing the construction, capacity and maintenance of existing roads in order to facilitate the flow of goods and people transport traffic.

e. Organizing the construction of office infrastructure, public facilities and social facilities to support the improvement of services for the community.

f. Organizing the arrangement of urban slum areas to create a neat, clean, green and healthy residential environment.

g. Together with the central government and the provincial government to provide cheap housing for low-income people.

h. Carry out routine maintenance by means of self-management of urban infrastructure which is the responsibility of the Public Works Department.

i. Organizing coaching for construction service partners and controlling construction quality in order to produce quality buildings.

j. Maintain and manage heavy equipment and testing equipment owned.

In collaborating with relevant stakeholders, there is a process towards Collaborative Governance. These stages or processes refer to the concept (Ansell \& Gash, 2007) which uses 5 stages to measure the collaboration process, namely:

1. Face to Face Dialogue; Face to face dialogue or face-to-face meetings are meetings between various parties in a location and at the same time so that direct or interactive dialogue occurs between the various parties to discuss a common interest. In carrying out regular stakeholder meetings, it is carried out every month. However, not all stakeholders participate in these regular meetings. Face to face dialogue is carried out in the form of meetings and events. Traffic itself is a face to face dialogue between stakeholders. Dialogue or face-to-face meetings are still held when there are events such as the road safety to zero accident festival, major holidays, 17 August and the like. So, this dialogue or face-to-face meeting is only held for momentum.

2. Trust building; Trust building is an effort to build trust that the parties do have the same intention in an effort to achieve common goals, trust building can be started by building communication between stakeholders, As in other arena partnerships, trust has always been the key word for success in managing these three sector partnerships, Trust between parties can be an important capital to overcome the differences that cannot be avoided in the development of partnerships involving institutions of different cultures and traditions. However, in collaboration between stakeholders in overcoming accidents, the author sees that trust building is still lacking, this can be seen from the results of interviews that the author has done where statements from the Department of Public Housing, Settlement Areas, Cleanliness and Parks of Tanjungpinang City to assist the needs and monitoring are not routinely carried out, and from the results of field research, many infrastructures are no longer feasible, this causes a lack of trust between stakeholders and the community. Build trust in partners, both organizations and also in this context to the community who are used as objects to provide an understanding of traffic accident prevention itself.

3. Commitment To Process; Commitment to Process is an agreement to carry out a process in order to achieve the desired goal, having the same commitment means that each party has its own relationship to overcome problems and solutions, that this process is a common property and is open to each other to get benefits, the reality in the moonitoring 
field it is not routinely carried out, and many road facilities have been damaged. Stakeholder commitment is also lacking according to the author as seen from the results of field research, supervision and maintenance of steady roads. The commitment in this collaboration process from each stakeholder in this case can be said to be the same, namely they both want to reduce the number of traffic accidents in Tanjungpinang City. It can be seen that the trust between stakeholders is already here, because it is not impossible that there could be a dilemma in carrying out this commitment. For example, stakeholders must comply with the results of the deliberation as a form of commitment even though the decision requires joining stakeholders with different views. So, this commitment requires trust so that the responsibilities of each stakeholder can be carried out properly.

4. Share understanding; Share understanding in handling this accident is to share understanding and understanding that this forum is a shared property and responsibility, identify problems in order to have a common understanding between stakeholders and realize the basic values that form the basis of this forum. Various understandings and understandings have been carried out by the Tanjungpinang Police Traffic Unit which has the authority to deal with accidents in Tanjungpinang City. Other stakeholders also conduct counseling both between members, schools and to the community. Mutual understanding is still not as expected. The regulations that were made jointly to support this mutual understanding have not been carried out by each of the stakeholders. Because in a collaborative process these stakeholders only follow vertical regulations from the central government and there is no result of a common understanding, which should develop a common understanding so that a collaboration can be said to be successful.

5. Intermediate Outcomes; Intermediate outcome is a temporary result of an ongoing process that provides benefits and strategic value. Interim results from collaboration between stakeholders. In accordance with Bardach's theory in (Sudarmo, 2015) which defines collaboration as a form of joint activity by two or more institutions that work together aimed at increasing public value rather than working alone, the interests of the government, the private sector, and the community. In accordance with the theory above, the researcher argues that every stakeholder involved gets an intermediate outcome from collaboration between stakeholders in accident prevention. In accordance with Bardach's theory in Sudarmo (2015: 195) which defines collaboration as a form of joint activity by two or more institutions that work together aimed at increasing public value rather than working alone, the interests of the government, the private sector, and the community.

In accordance with the theory above, the researcher argues that every stakeholder involved gets an intermediate outcome from collaboration between stakeholders in dealing with traffic accidents, this researcher concludes from the results of interviews with each stakeholder, reducing the number of traffic accidents, outreach to the community, especially schools regarding the understanding of safety. in traffic, and the prevention of traffic accidents carried out between stakeholders went well and successfully. This means that this collaboration has a good impact on each stakeholder, because the literature shows that collaboration will occur when the goals and benefits of collaboration are concrete. In 5 stages of Collaborative Governance, namely (1). Face to face, (2). Trust building, (3). commitment to process, (4). Share understanding (5). Intermediate outcome proposed by (Ansell \& Gash, 2007).

\section{CONCLUSION}

Collaborative governance that is carried out in dealing with traffic accidents is the Tanjungpinang City Police Traffic Unit, Tanjungpinang City Transportation Service, PT. Jasa Raharja (Persero) Tanjunginang Representative, Department of Public Housing, Residential Areas, Cleanliness and Parks of Tanjungpinang City, Department of Public Works and Spatial Planning of Tanjungpinang City in handling traffic accidents, which involves interstakeholders. Based on the results of research and findings in the field, through interviews, it was found the fact that the collaboration model that occurred in handling traffic accidents in 
Tanjungpinang City was included in the "tertiary collaboration" category. Tertiary collaboration is a form of collaboration based on the attitude of each party that is purely opportunistic. The parties prioritize their respective interests rather than the larger interest (the state). The characteristic of this organization is that it is very loose and easy to break. Due to the collaboration carried out by parties who have the authority in handling traffic accidents, in its implementation in the field, the actors do not have a work culture that is independent of the hierarchy so that it does not encourage the determination of making new provisions in order to empower each party or actor to achieve goals. together.

In the process of Collaborative Governance is a process that becomes an important stage so that all planning can be well coordinated. In the process of simultaneous collaboration between stakeholders in traffic accident prevention, it is possible to combine related elements in order to get results in accordance with what is the goal. Through this stage of the process, the results to be achieved in the intermediate outcome stage or the intermediate results occur in the same direction. Thus, it is hoped that the collaboration between the related parties can run optimally. Through the collaborative governance concept approach of Ansell and Gash that has been perfected or modified it will increase the active participation of each stakeholder involved so that there is a commonality of motion and steps in overcoming traffic accidents in Tanjungpinang City. At this stage the parties involved achieve the expected goals and benefit from concrete collaboration.

\section{REFERENCE}

Ahmadi, A. (2004). Sosiologi Pendidikan. PT. Rineka Cipta.

Ansell, C., \& Gash, A. (2007). Collaborative governance in theory and practice. Journal of Public Administration Research and Theory, 18(4), 543-571. https://doi.org/10.1093/jopart/mum032

Djumara, N. (2008). Modul 4 Pengembangan Budaya Kerja Aparatur, Diklat Teknis manajemen Sumber Daya Manusia Pegawai Negeri Sipil (Human Resource Management). Lembaga Administrasi Negara Republik Indonesia.

Lestari, E., \& Maliki, M. A. (2001). Negosiasi, Kolaborasi Dan Jejaring Kerja. Lembaga Administrasi Negara.

Lindeke, L. L., \& Sieckert, A. M. (2005). Nurse-Physician Workplace Collaboration. Online Journal of Issues in Nursing, 10(1).

Marshall, E. M. (1995). Transforming the Way We Work: The Power of the Collaborative Workplace. American Management Association.

Moleong, L. J. (2014). Metodologi Penelitian Kualitatif Edisi Revisi (Revisi). Remaja Rosda Karya.

Narwoko, J. D. (2004). Sosiologi Teks Pengantar dan Terapan. Pren ada Media.

Nawawi, H. (1984). Administrasi Pendidikan. PT. Gunung Agung.

Ndraha, T. (2003). Kybernology (IImu Pemerintahan Baru) Jilid 1 dan 2. Rineka Cipta.

Pamudji, S. (1993). Kepemimpinan Pemerintahan di Indonesia. Bumi Aksara.

Pratikno. (2007). Governance dan Krisis Teori Organisasi. Jurnal Kebijakan Dan Administrasi Publik, 11(2), 121-138. https://doi.org/10.22146/jkap.8563

Raharja, S. U. J. (2010). Pendekatan Kolaboratif Dalam Pengelolaan Daerah Aliran Sungai Citarum. Jurnal Bumi Lestari, 10(2), 222-235.

Rasyid, R. (2000). Makna Pemerintahan: Tinjauan Dari Segi Etika Dan Kepemimpinan. Mutiara Sumber Widya.

Sugiyono. (2012). Metode Penelitian Kuantitatif, Kualitatif dan R \& D. Alfabeta.

Syani, A. (1994). Sosiologi: Skematika, Teori dan Terapan. Bumi Aksara.

Zeho, F. H., Prabowo, A., Estiningtyas, R. A., Mahadiansar, M., \& Sentanu, I. G. E. P. S. (2020). Stakeholder collaboration to support accountability in village fund management and rural development. Journal of Socioeconomics and Development, 3(2), 89-100. https://doi.org/10.31328/jsed.v3i2.1395 